\title{
Spatio-seasonal patterns of demersal fish communities on the French Guiana Coast
}

\author{
Le Joncour Anna ${ }^{1}$, Blanchard Fabian ${ }^{1,}{ }^{*}$, Tagliarolo Morgana ${ }^{1}$
}

1 Ifremer, UMSR LEEISA (CNRS, Université de Guyane, Ifremer), 275 Route de Montabo, BP50477, 97323 Cayenne Cedex, French Guiana, France

* Corresponding author, Fabian Blanchard, email address : fabian.blanchard@ifremer.fr

Anna.le.joncour@ifremer.fr ; Morgana.tagliarolo@ifremer.fr

\begin{abstract}
:
Estuarine and coastal areas are often considered as hotspots due to their high diversity and ecological importance. However, communities living on those areas are often submitted to fishery and climate change pressures causing modifications on fish assemblages. French Guiana's coastal shelf is characterised by warm waters with high turbidity and low salinity caused by the large river discharges from the Amazon and nearby estuaries. The high productivity of these areas supports fisheries and aquaculture activities. However, the structure and dynamics of coastal fish populations in French Guiana have seldom been studied. The aim of this study was to understand the effect of environmental conditions, as well as the influence of the coast and nearby estuaries on the spatio-seasonal variability of demersal fish communities living in shallow coastal waters (less than $20 \mathrm{~m}$ depth). Data were collected from two fishing campaigns using a multi-filament drifting net during the rainy and dry season at 55 sampling stations along the coast. Results showed a high spatial patchiness and no clear seasonal pattern. Higher abundances and diversities were observed near estuaries where both marine and estuarine species were cohabitating. The high number of rare species and the aggregative behaviour recorded in this study suggest that those communities could be particularly affected by climate change, pollution and overfishing. In the light of increasing pressures expected in this area, new regulations and management programs should be developed to ensure food security and biodiversity conservation.
\end{abstract}

\section{Highlights}

- French Guiana coastal waters are primarily influenced by the nearby estuaries. Demersal fish population is mostly estuarine. Important role of local estuaries on fish communities structure. Aggregation behaviour was recorded during the rainy season near estuaries. Management programs need to be developed to protect biodiversity.

Keywords : French Guiana, Coastal community, Estuary, Diversity, Tropical waters, Fisheries management 


\section{Introduction}

Coastal waters in wet tropical areas are characterised by high precipitation and stable water temperatures that, together with important freshwater runoffs, lead to large nutrient fluxes, high productivity and sediment accumulation (Nittrouer et al., 1995). The high productivity of coastal areas supports a large number of fishing and aquaculture activities (Salas et al., 2007). Despite their important contribution to national economics, the composition of marine communities and their spatial and temporal changes are rarely studied (Barletta et al., 2010; Willems et al., 2015a). In recent years, several marine fisheries activities have shown signs of decline or collapse caused mainly by habitat loss, environmental changes and poor fisheries management (Barletta et al., 2010; Botsford et al., 1997; Hutchings and Reynolds, 2004; Sanz et al., 2017).

The Guianese shelf in northeastern South America is characterised by shallow coastal waters, lower salinities and high turbidity typical of estuarine areas (Blaber, 2002). French Guiana's littoral is directly influenced by the Amazon, the world's largest estuarine basin, with a high annual water flow which leads to the input of sediment creating large moving mudflats along the coast. The effects of the Amazon can be seen up to $400 \mathrm{~km}$ from the mouth (Froidefond et al., 2004, 2002; Hu et al., 2004). The presence of several estuaries and mangrove areas along the coastline makes these waters partly estuarine as far as their fish communities are concerned (Blaber, 2002; Lowe-McConnell, 1987). The high vegetation density of mangroves contributes to coastal protection against waves and wind as well as erosion (Barbier et al., 2011). Providing raw material and food, they also contribute to the maintenance of local fisheries by playing a crucial role as nurseries for coastal and estuarine species (Blaber, 2000), and by providing ideal feeding grounds for juveniles (Rousseau et al., 2018).

The marine shelf ecosystem of French Guiana is subjected to various pressures (increasing population, fisheries exploitation, climate change, globalisation of trade, oil and gold exploration, terrigenous and continental inputs related to human activities). Climate change and fisheries exploitation are among the most important factors causing alteration of ecosystems dynamics and 
demersal population assemblages (Bernard, 2006; Lampert, 2013; Poulard and Blanchard, 2005; Rivierre, 2007; Travers et al., 2007). Fisheries activities have been shown to modify the spatial distribution of fish communities, population structure and size structure (Blaber, 2000; Camara et al., 2016; Perry, 2005). Rising sea-surface temperature can lead to a diminution of the net primary production produced by phytoplankton (Behrenfeld et al., 2006) having consequences on fisheries yields and food-web dynamics (Diop et al., 2018c, 2018a, 2018b; Hoegh-Guldberg and Bruno, 2010; Lampert, 2013; Ware, 2005).

Over 3000 tons of fish worth 9 million euros are produced each year in French Guiana, constituting one of the most important economic activities. Of the different fishing activities (coastal artisanal fishery, offshore shrimp trawling and longline fishing), the most important resource (as in tons per year) is the coastal white fish dedicated to the local market and contributing to food security (Cissé et al., 2013; Vendeville and Baudrier, 2006). The small-scale coastal fishery, with landing points spread along the coast, operates up to $16 \mathrm{~km}$ offshore at depths of 0-20 m. This multi-species fishery exploits more than 30 coastal species (weak fish, cat fish, shark, grouper). In terms of volume the most important species includes the Acoupa weak fish (Cynoscion acoupa (Lacepède, 1801)), the Crucifix sea catfish (Sciades proops (Valenciennes, 1840)) and the Green weakfish (Cynoscion virescens (Cuvier, 1830)) representing around 75\% of the annual catch between 2014 and 2018 (Observateurs du SIH, 2018a, 2018b, 2017, 2016, 2014). French Guiana's fast growing population has nearly doubled in 20 years; the demand for fishery products is therefore predicted to increase in the near future (IEDOM, 2018) hence potentially inducing increased pressure on the coastal fish communities. Unfortunately, only simple economic models based on coastal fishery data are currently available (Cissé et al., 2015, 2014, 2013). Very few studies have focused on the coastal demersal faunal assemblages of French Guiana, and the nearshore waters of the coastal fringe from 0 to $20 \mathrm{~m}$ depth, have never been studied before (Artigas et al., 2003). Recent studies have been published on fish larvae in estuaries (Rousseau et al., 2018) but nothing on adults, which are exploited in local coastal fisheries. 
90 Understanding the effect of environmental conditions on seasonal and spatial patterns is the first

91 step for a better understanding of the ecosystem ecology and the development of effective management of the area. Our study provides a first general overview of the effects of environmental variables on coastal demersal fish communities in French Guiana. Our aims were 1) to analyse seasonal and spatial variability of fish assemblages and 2) to identify which abiotic factors were driving these variabilities. We hypothesise that the presence of estuaries could define fish assemblages due to changes in the environmental conditions on those areas. 


\section{Material and methods}

\subsection{Study area}

French Guiana is situated on the northeastern coast of South America, between the northern limit of Brazil and the southern border of Suriname (Artigas et al., 2003). The French Guianese's maritime space is about $320 \mathrm{~km}$ long and, because of the geological characteristics of the continental margins (from $08^{\circ} 33^{\prime} \mathrm{N}$ to $10^{\circ} 18^{\prime} \mathrm{N}$ and from $48^{\circ} 47^{\prime} \mathrm{W}$ to $51^{\circ} 52^{\prime} \mathrm{W}$ ), it extends beyond 200 nautical miles from the baseline (from $04^{\circ} 30^{\prime} \mathrm{N}$ to $05^{\circ} 48^{\prime} \mathrm{N}$ and from $51^{\circ} 38^{\prime} \mathrm{W}$ to $53^{\circ} 56^{\prime} \mathrm{W}$ ). The continental shelf extends out to sea with a slow and regular slope beyond the EEZ (about $126000 \mathrm{~km}^{2}$ of EEZ) (Durand, 1959; Gratiot et al., 2005). Heavy and continuous discharge of organic matter from the Amazon River and the major Guianese Rivers (Oiapoque, Approuague and Maroni) explain the moving mudflats found along the benthic coastal zone (0 to $20 \mathrm{~m}$ depth) (Anthony et al., 2013, 2010; Froidefond et al., 2004). The input of freshwater from the rivers also results in turbid and brackish coastal waters, a phenomenon emphasised during the rainy season due to the heavy tropical rainfalls increasing the water flow (Froidefond et al., 2002). Coastal habitat in the studied area is homogeneous and characterised by dynamic fluid mud banks moving along the coastline at $>1 \mathrm{~km}$ per year (Vendeville and Baudrier, 2006). The macrofaunal community is characterised by very low diversity and richness and animals are generally small due to the instability and softness of the substrate (Jourde et al., 2017).

\subsection{Sampling sites}

Overall 32 stations were selected from the east to the west coast of French Guiana in proximity to the $10 \mathrm{~m}$ isobath (Figure 1). The stations were defined using a stratified random sampling procedure (coordinates of each station are available in the annex table A.1.). This method involved the division of the area into various homogeneous groups and randomly sampling a predefined number of stations within each group. Stations extended from as close as $4 \mathrm{~m}$ deep to depths of $14 \mathrm{~m}$. Due to 
122 (respectively), with 24 common stations between the two seasons.

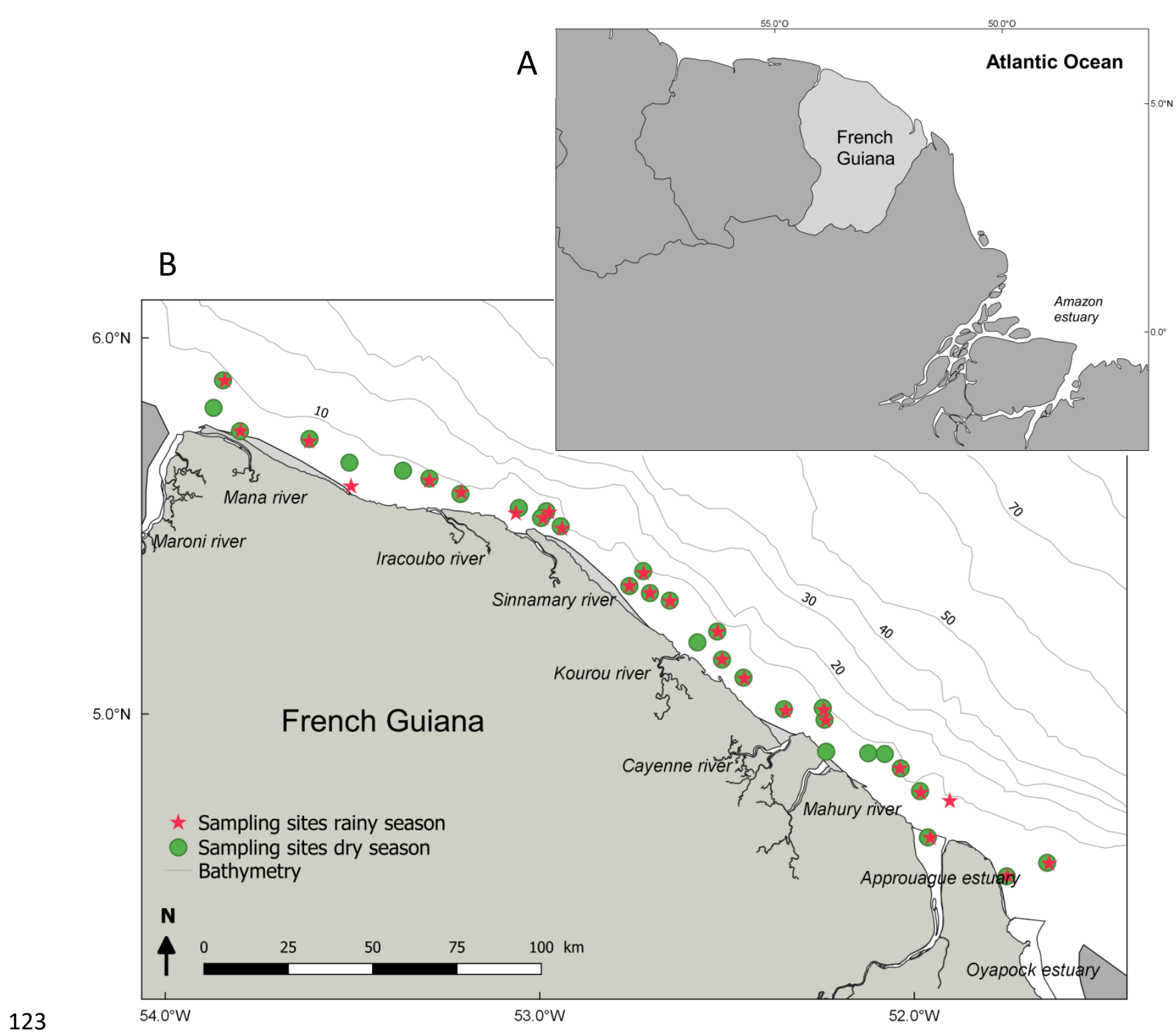

124 Figure 1. Study area (A) Location of French Guiana (coloured in light grey) in South America compared to the Amazon estuary in Brazil (B) French Guiana coastline from west to east representing the sampling stations for both scientific campaigns, and the major rivers and estuaries. 

long and it can stay out at sea for up to 10 days.

132

At each sampling station, a drifting net (multifilament drifting net, $3 \mathrm{~m}$ high, with two equal portions of 60 and $70 \mathrm{~mm}$ side mesh size totalling $600 \mathrm{~m}$ long) was towed for 90 minutes (measured from the moment that the trawl arrives on the bottom to the beginning of the hauling process) close to the seabed. All stations were sampled during daytime. All fish species caught were identified to species level directly onboard. Leopold (2005) was used for species identification as well as expert opinion.

GPS sampling position (latitude $X$ and longitude $Y$ coordinates), date, time and depth were recorded at the beginning and end of towing for each trawl sample (Table A.1). Additional environmental parameters were measured at each station with a multi-parameter probe (YSI EXO2 Sonde) and included profiles of: maximum depth of the seafloor (Zmax, in meters, $\mathrm{m}$ ), temperature ( $\mathrm{T}$ in Celsius degrees, ${ }^{\circ} \mathrm{C}$ ), turbidity (Turb FNU in Formazine Nephelometric Unit, FNU), salinity and pH (Table A.3.). Environmental measures were taken at the rear end of the boat as turbulence at the front of the boat can disrupt the measurements. The net's height totalled around three meters when placed in the water, therefore mean values of the last three meters of the environmental profiles were calculated to characterise each station. Tidal height (positive for flood and negative for ebb tide) was estimated for each sampling by employing the tidal estimation of the SHOM (Service Hydrographique et Océanographique de la Marine). Distance to the coast $(\mathrm{m})$ and to the estuary $(\mathrm{m})$ was calculated with QGIS (2.18 Las Palmas) using the coastline and the middle of the estuary mouth respectively (Table A.3.).

\subsection{Statistical methods and numerical data analysis}

To evaluate the effectiveness of sampling and to estimate the validity of using species richness as a proxy for taxonomic diversity, the rarefaction curves (in terms of samples and individuals) were estimated for both seasons (Gotelli and Colwell, 2001). Rarefaction curves were drawn and the asymptote was calculated using the Lomolino model of fitspecaccum using the vegan package in $R$ 
155 (Dengler, 2009; Lomolino, 2000). In the Lomolino model the number of species (S) is expressed as in 156 the following equation:

$157 S=$ Asym $/\left(1+\right.$ slope $\left.^{\log (x m i d / \text { area })}\right)$

158 with Asym: asymptotic maximum number of species; slope: maximum slope of increase in richness;

159 xmid: area where half of the maximum richness is achieved.

160 Species occurrence is a percentage representing the number of sites where a species is sampled from

161 the total number of sites. There are 4 frequency classes according to the scale proposed by

162 Charbonnel et al., (1995) in Tessier et al., (2005): permanent species of the habitat (> 75\%), frequent

163 species (50-74.9\%), scarce species (25-49.9\%) and rare species ( $<25 \%)$. Frequency $(F)$ is calculated as:

$164 \mathrm{~F}=\left(\frac{\mathrm{Pa}}{\mathrm{P}}\right) \times 100$

165 with Pa: total number of sites containing the species; P: total number of sites.

166 To evaluate the spatial and seasonal variability of fish communities, four indices were calculated for

167 each site and season (table 1 ).

168 Table 1. Definition and formula of the different diversity indices calculated in this study to 169 characterise species diversity. Abb.: abbreviation. Archimedes' constant $\mathrm{Pi} \approx 3.141592 \ldots, \mathrm{Hmax}=$ 170 maximum diversity or $\log _{2} \mathrm{~S}$

\begin{tabular}{lllll}
\hline Index & Abb. & Definition & Formula & Reference \\
\hline Abundance & A & $\begin{array}{l}\text { number of individuals sampled per } \\
\text { species in each station }\end{array}$ & \\
\hline $\begin{array}{l}\text { Species } \\
\text { richness }\end{array}$ & $\mathrm{S}$ & $\begin{array}{l}\text { number of species sampled per } \\
\text { station }\end{array}$ & & \\
\hline $\begin{array}{l}\text { Shannon's } \\
\text { diversity }\end{array}$ & $\mathrm{H}^{\prime}$ & $\begin{array}{l}\text { based on species richness, as well } \\
\text { as the distribution of individuals } \\
\text { within the species }\end{array}$ & $\mathrm{H}^{\prime}=-\sum_{\mathrm{i}=1}^{\mathrm{S}} \mathrm{p}_{\mathrm{i}}\left(\log _{2} \mathrm{p}_{\mathrm{i}}\right)$ & $\begin{array}{l}\text { (Jost, 2006; } \\
\text { Shannon, 1948) }\end{array}$ \\
\hline
\end{tabular}




\begin{tabular}{lll}
\hline Pielou $\quad \mathrm{J} \quad \begin{array}{l}\text { Equality of proportional } \\
\text { abundances }\end{array}$ & $\mathrm{J}=\frac{\mathrm{H}^{\prime}}{\mathrm{H}_{\max }}$
\end{tabular}

171

172 Seasonal differences of fish diversity (S, A, H and J) across the common stations between the two

173 seasons (24 stations) was statistically tested using paired $t$-tests per permutation (Legendre and

174 Blanchet, 2015).

175 Spatial and seasonal variability of environmental variables and fish abundances were tested using PERmutational Multivariate ANalysis Of VAriance (PERMANOVA) (Anderson, 2001). The test was run with adonis2 script (vegan package for R) with 9999 permutation and a Bray-Curtis distance. Two fixed factors were tested: season $(d f .=1)$ and site $(d f .=28)$. PERMANOVA test was performed on rootsquared transformed fish abundances and on the normalised environmental dataset.

An ordination of fish abundances Bray-Curtis matrix was conducted by applying a nonmetric multidimensional scaling (nMDS). The metaMDS function of the vegan package in $\mathrm{R}$ was employed with 500 random starts and two dimensions (Oksanen et al., 2010). The potential relationship between sites communities, environmental variables and species presence was fitted by adding these vectors to the ordination using enfit function of the vegan library (9999 permutations). The environmental and species variables with a $p$-value $<0.05$ indicating a significant correlation were added to the nMDS plot.

Since no seasonal differences were detected in fish communities, the entire data set was employed for further analysis. Draftsman plot and Spearman correlation test were performed on the environmental data available (latitude, longitude, sea water temperature, pH, salinity, depth, turbidity, distance from the coast, distance from the closest estuary, tidal height). Longitude was

191 excluded from all analysis due to its significant correlation with latitude, $\mathrm{pH}$ and salinity, since the 192 inclusion of highly correlated variables tends to affect variance estimations and hence the 
significance levels. The strong correlation between latitude and longitude (Spearman correlation coefficient $=-1, p<0.001$ ) is probably an artefact of the stratified sampling and the shape of the coast.

A Principal Components Analysis (PCA) was employed to illustrate the main trends in our environmental (sea water temperature, $\mathrm{pH}$, salinity, depth, turbidity, tidal height) and spatial (latitude, distance from the coast, distance from the closest estuary) data sets with PRIMER v.7.0.13 (CPRIMER-e). All variables were normalised by subtracting the mean and dividing by the standard deviation and the matrix samples vs variables was used to create the PCA.

Spatial correlation and the correlation between environmental variables and biological data (fish total abundance and species richness) were performed by employing a Generalised Additive Model (GAM). GAMs are generalisation of generalised linear models with their ability to model non-linearity in the relationship between the response and predictors by using non-parametric smoothers (Maravelias, 2001). Two models were computed, one to test spatial variability (distance from the coast, distance from the closest estuary and latitude) and one for the environmental parameters (temperature, salinity, $\mathrm{pH}$, depth, turbidity, and tide height). A Poisson distribution was chosen since counts are assumed to follow a Poisson distribution (Yemane et al., 2010). The goodness of fit was assessed by examining the diagnostic plots and by adjusting the Akaike Information Criterion (AIC) in a step-by-step procedure. The relative proportion of the deviance explained by each predictor was estimated on the selected models. The two sites with extreme high abundance due to Lobotes surinamensis were excluded from the GAM abundance analysis since a preliminary test showed that those two sites could be considered as outliers.

A multivariate distance-based linear regression model (DISTLM, forward selection procedure, selection criteria: $R^{2}$ ) was employed to evaluate the relationship between fish assemblage data and environmental variables. The fish abundance data were firstly root-squared transformed, the resemblance matrix was constructed using a Bray-Curtis dissimilarity, the environmental and spatial variables were normalised and used as predictors. A distance-based redundancy analysis (dbRDA) 
218 was then used to visualise the DistLM model in a multi-dimensional space (Legendre and Anderson,

219 1999).

220 Map representations were made on QGIS 2.18 Las Palmas (QGIS Development Team, 2018), and all

221 statistical analyses were performed in R v.3.4.0 (R Core Team, 2017) using the packages vegan and

222 PRIMER v.7.0.13 (CPRIMER-e) with the Permanova add-on software (Anderson et al., 2008; Clarke

223 and Gorley, 2015). 


\section{Results}

Throughout both campaigns, 1807 fish were sampled, from 57 different species, for 55 samples (26 during the rainy season and 29 during the dry season). The asymptote of the number of species was not reached with the 55 samples. Ideally more stations should have been sampled. An estimated 3537 species were not sampled according to the asymptote calculated by the Lomolino model. Fewer species were sampled during the rainy season, with an exaggerated difference in terms of species/individual sampled rather than species/samples sampled (Figure 2).
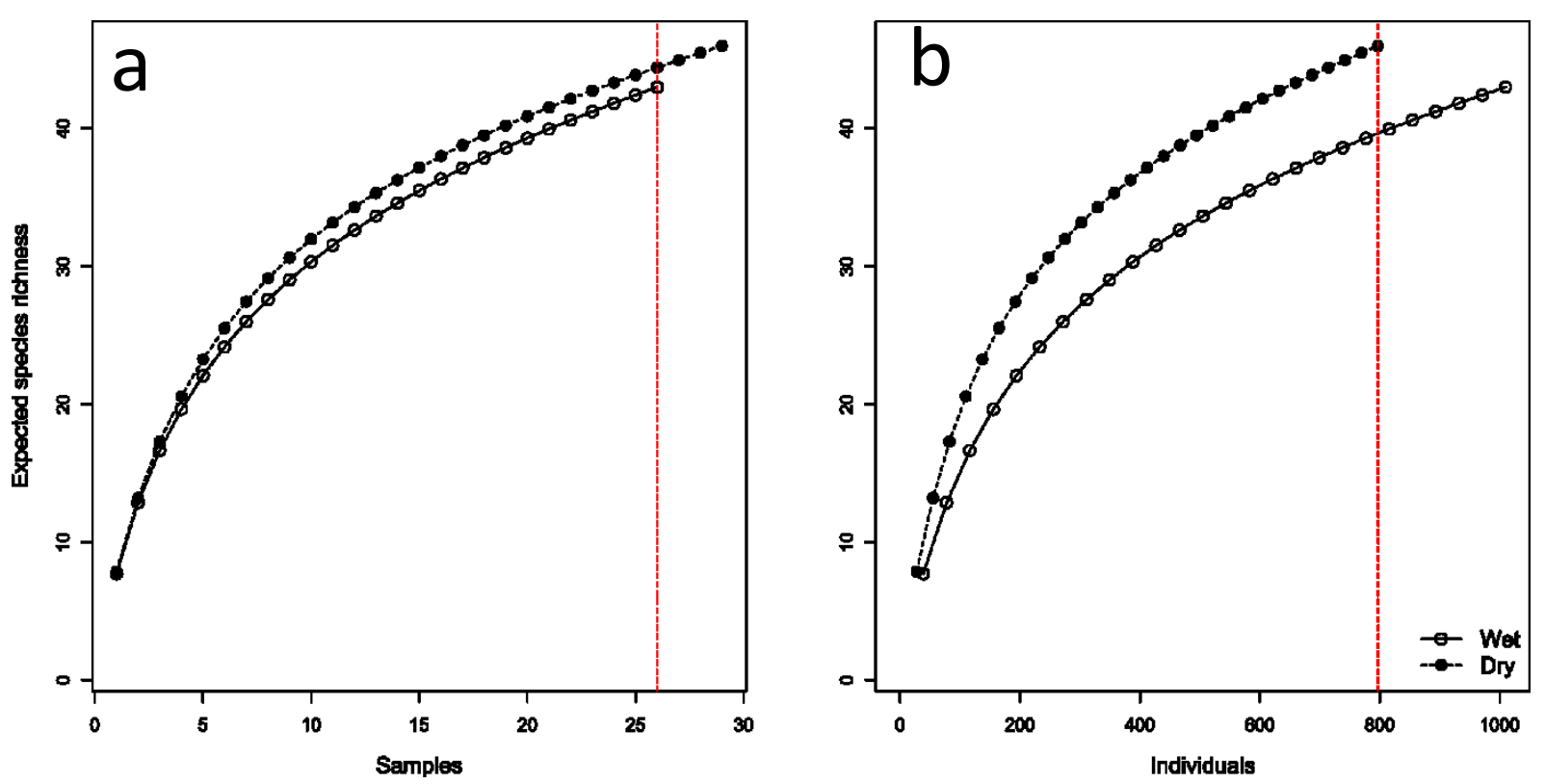

Figure 2. (a) Sample- and (b) individual-based rarefaction curves defining the number of species encountered in a number of samples and individuals. On average (for both seasons) 92.6 species are expected, to reach the asymptote when considering samples (slope 1.94) compared to 94.5 when considering individuals (slope 1.71). The most abundant species was Sciades proops (the crucifix sea catfish) with $83.6 \%$ of occurrence in the samples and it can be considered as a permanent species. Only three species were present in 
more than $50 \%$ of the samples: Sciades proops, Cynoscion virescens (the green weakfish) and Bagre bagre (Linnaeus, 1766) (the coco sea catfish). Twenty five species occurred in $<5 \%$ of the samples, and 16 species were very rare, occurring each in a single sample. The species list, their occurrence, relative frequency and the total abundance of each species sampled can be found in the appendix (Table A.2.).

Species richness (S) varied between 1 and 19 species per station (Figure 3.A). Species richness is quite 245 even along the coast of French Guiana, with most stations having between 7 and 13 species. Only 3 246 stations had more than 13 species. In terms of abundances (A), individuals ranged from 1 to 235 per 247 station with a mean of $32.9 \pm 41.9$ individuals. Some abundance hotspots are visible on the map 248 (Figure 3.B), indicating high variability along the coast. These hotspots were mostly situated at the Oyapock river mouth, around the Salvation Islands and around the islands of Rémire near Cayenne. One species (Lobotes surinamensis (Bloch, 1790)) was very abundant at two stations sampled during the rainy season (GY2D33 and GY4D12) with 208 individuals in each station and less than 179 individuals altogether on the rest of the coast (Figure 3.C). 

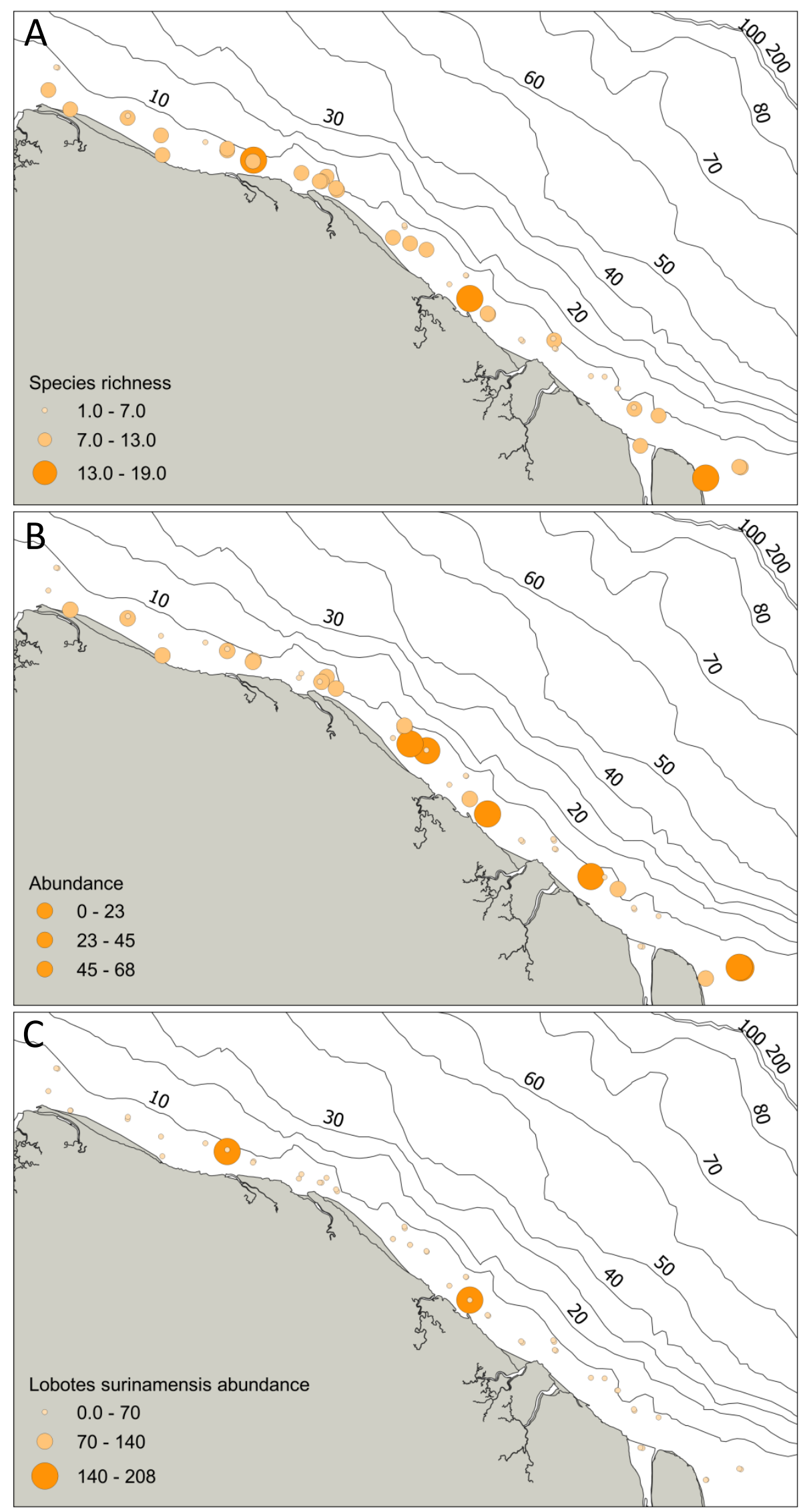
Figure 3. Map of the distribution of the species richness and abundance along the coastline of French Guiana with the major coastal estuaries. (A) Species richness (B) Abundance of all species except Lobotes surinamensis (C) Abundance of Lobotes surinamensis.

\subsection{Environmental variables}

Salinity, temperature and turbidity values were significantly different between the dry and rainy seasons ( $t$-test, $p<0.05$ ). Salinity was on average higher during the dry season (mean difference 2.335, $t=-3.322)$, while the temperature and the turbidity had higher values during the rainy season (mean diff. 1.7686, $t=5.291$ and mean diff. 57.433, $t=2.268$ respectively) (Figure 4). The PERMANOVA test showed significant seasonal $(F=8.04, p<0.001)$ and spatial differences $(F=122.06$, $\mathrm{p}<0.001)$ on the environmental variables. The mean and standard deviation, minimum and maximum values of temperature, salinity and turbidity for the dry and rainy season are presented in table 2 .
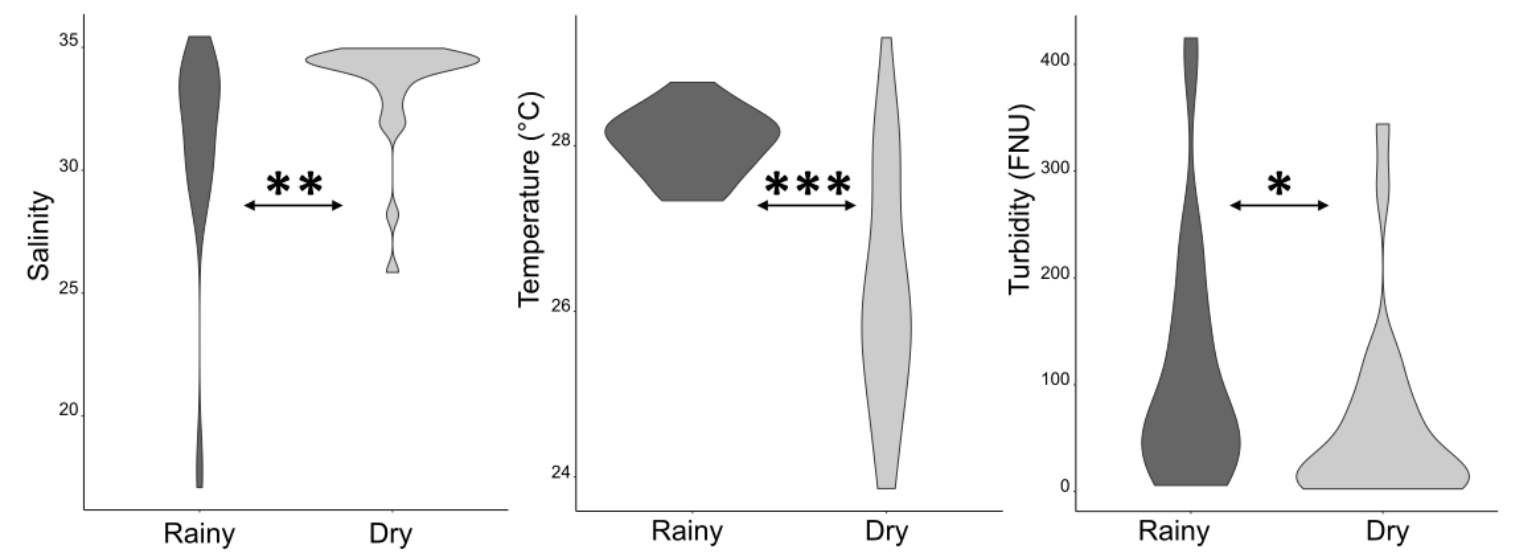

Figure 4. Violin plots representing the variations in salinity, temperature and turbidity between the rainy season and the dry season. Scales and units are different for each parameter (Signif. codes: 0 $\left.<^{* * *}<0.001<* *<0.01<*<0.05<.<0.1<<1\right)$. Degrees of freedom $=21$. 
Table 2. Mean, standard deviation and range of temperature $\left({ }^{\circ} \mathrm{C}\right)$, salinity and turbidity (FNU).

\begin{tabular}{l|llll|lllll|lllll}
\hline \multicolumn{5}{c|}{} & \multicolumn{4}{c|}{ Salinity } & \multicolumn{4}{c}{ Turbidity } \\
Season & Mean & SD & Min & Max & Mean & SD & Min & Max & Mean & SD & Min & Max \\
& & & & & & & & & & & \\
\hline Rainy & 28.04 & 0.39 & 27.34 & 28.77 & 31.09 & 4.41 & 17.09 & 35.44 & 111.08 & 112.38 & 5.71 & 424.62 \\
Dry & 26.25 & 1.46 & 23.86 & 29.30 & 33.50 & 2.16 & 25.84 & 34.96 & 60.76 & 86.14 & 2.44 & 344.03 \\
\hline
\end{tabular}

273

274 The PCA of the normalised environmental conditions shows that stations sampled during the dry

275 season tend to have higher salinities and $\mathrm{pH}$, while rainy season stations have higher temperatures

276 and turbidity (Figure 5). The first two principal components of the normalised environmental dataset explained $52.5 \%$ of the total variance.

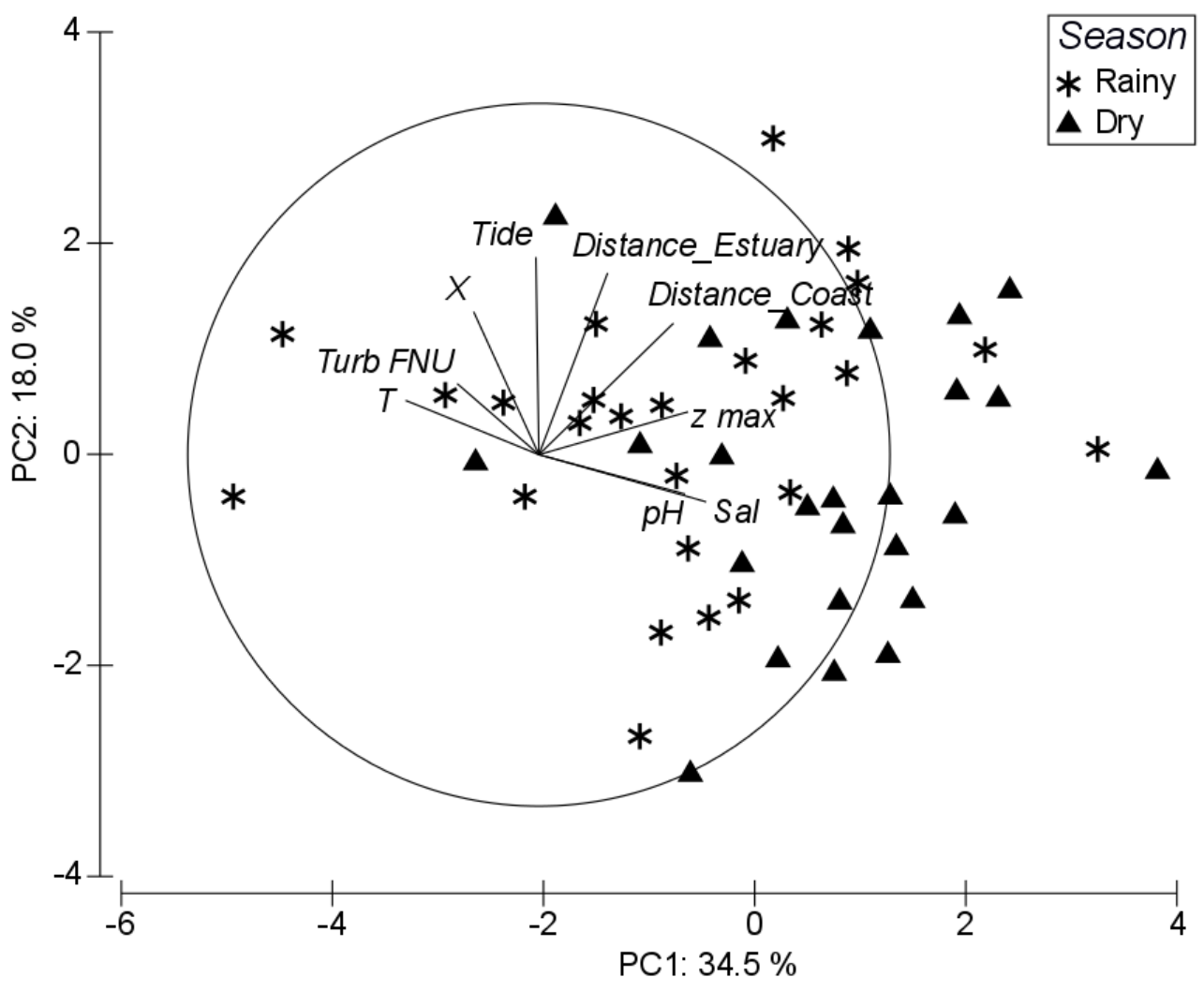

Figure 5. Principal Components Analysis (PCA) of the normalised environmental and spatial variables. 
282 No significant differences in terms of species richness, evenness, diversity (Shannon) and abundance 283 between the two seasons were detected for the common stations (T-paired test, 9999 perms) (Table 3). The results on the diversity index were strengthened by the PERMANOVA test showing no significant seasonal effect on species abundance matrix $(F=1.57, p>0.05)$. Therefore, samples from both seasons were pooled together to investigate spatial variability. dry season (9999 permutations). $\mathrm{df}=$ degree of freedom, $t=\mathrm{t}$-statistics.

\begin{tabular}{lllll}
\hline & \multicolumn{3}{c}{ Paired t-tests } \\
\cline { 2 - 5 } & $\mathrm{df}$ & Mean diff. & $t$ & $p$-value \\
\hline Species richness & 23 & -0.83 & -1.07 & 0.33 \\
Pielou's evenness & 21 & -0.02 & -0.29 & 0.78 \\
Shannon & 23 & -0.11 & -0.65 & 0.52 \\
Abundance & 23 & 11.83 & 0.95 & 0.41 \\
\hline
\end{tabular}
suggested that the main driving factors were depth and temperature $(p<0.05)$. Nine species were significantly driving the communities' differences between sites (Figure 6). Two sites could be seen as outliers in the MDS, and can be explained by the very low abundance of species collected at these stations. 


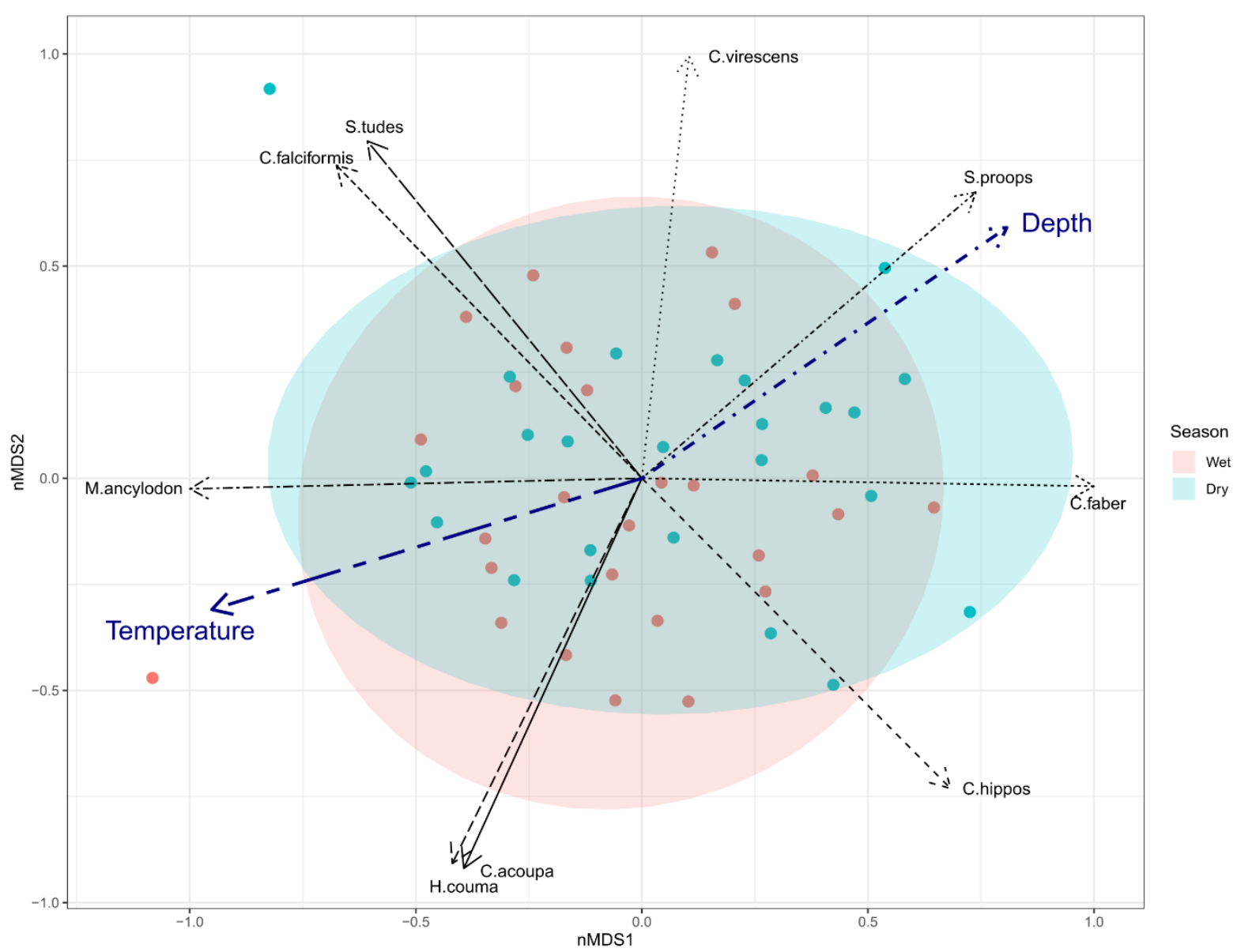

Figure 6. Non-parametric multidimentionam scaling (nMDS) plot for coastal fish assemblages during dry and wet season together.

Two sites were particularly different from the others due to extreme high abundances of Lobotes surinamensis (Figure 3.C) and were therefore removed for the following GAM analysis. Results of the GAM analysis on total abundance data showed that all spatial variables explained $48 \%$, and the environmental model explained $66 \%$ of the variance (both models significantly explained abundance data; $p<0.0001$ ). GAM model calculated on species richness and spatial data explained $57 \%$ of the variance and the one on environmental data, $47 \%$ (both models significantly explained species richness; $p<0.0001)$. of freedom. 


\begin{tabular}{|c|c|c|c|c|}
\hline GAM on abundance data & edf & Ref.df & Chi.sq & P value \\
\hline \multicolumn{5}{|l|}{ Spatial } \\
\hline Latitude & 4.9 & 4.9 & 89.32 & $<0.0001$ \\
\hline Distance from the coast & 6.9 & 7.0 & 83.3 & $<0.0001$ \\
\hline Distance from the estuary & 4.3 & 4.7 & 27.6 & $<0.0001$ \\
\hline \multicolumn{5}{|l|}{ Environmental } \\
\hline Temperature & 5.4 & 5.8 & 111 & $<0.0001$ \\
\hline Tide height & 4.1 & 4.6 & 5.4 & 0.3 \\
\hline Salinity & 5 & 5 & 29.7 & $<0.0001$ \\
\hline $\mathrm{pH}$ & 4.7 & 4.9 & 27.4 & $<0.0001$ \\
\hline Depth & 1 & 1 & 1.3 & 0.3 \\
\hline Turbidity & 4.3 & 4.7 & 61.3 & $<0.0001$ \\
\hline GAM on species richness & edf & Ref.df & Chi.sq & $P$ value \\
\hline \multicolumn{5}{|l|}{ Spatial } \\
\hline Latitude & 3.4 & 4.1 & 11.9 & $<0.05$ \\
\hline Distance from the coast & 6.1 & 6.7 & 19.6 & $<0.005$ \\
\hline Distance from the estuary & 1 & 1 & 2.4 & 0.1 \\
\hline \multicolumn{5}{|l|}{ Environmental } \\
\hline Temperature & 2.7 & 3.4 & 12.8 & $<0.01$ \\
\hline Tide height & 2.8 & 3.3 & 4.6 & 0.3 \\
\hline Salinity & 1.5 & 1.8 & 3.9 & 0.1 \\
\hline $\mathrm{pH}$ & 1.7 & 2 & 3.6 & 0.2 \\
\hline Depth & 1 & 1 & 2.1 & 0.1 \\
\hline Turbidity & 1.3 & 1.6 & 0.2 & 0.8 \\
\hline
\end{tabular}


To further investigate the relationship between species composition and environmental variables a

309 DistLM model was performed; results were visualised by a dbRDA (Figure 7.a). Three environmental variables, depth $(p<0.001,8 \%$ variance explained) temperature $(p<0.005,3.3 \%$ variance explained) and distance to the estuary ( $p<0.005,3.2 \%$ variance explained), contributed to the highest and significant percent of explained variation in the fish assemblage (Figure 7.b) explaining $14.6 \%$ of the variation in community structure. All variables except latitude $(X)$ and Tide have a significant relationship with the species multivariate data cloud when considered alone. The total
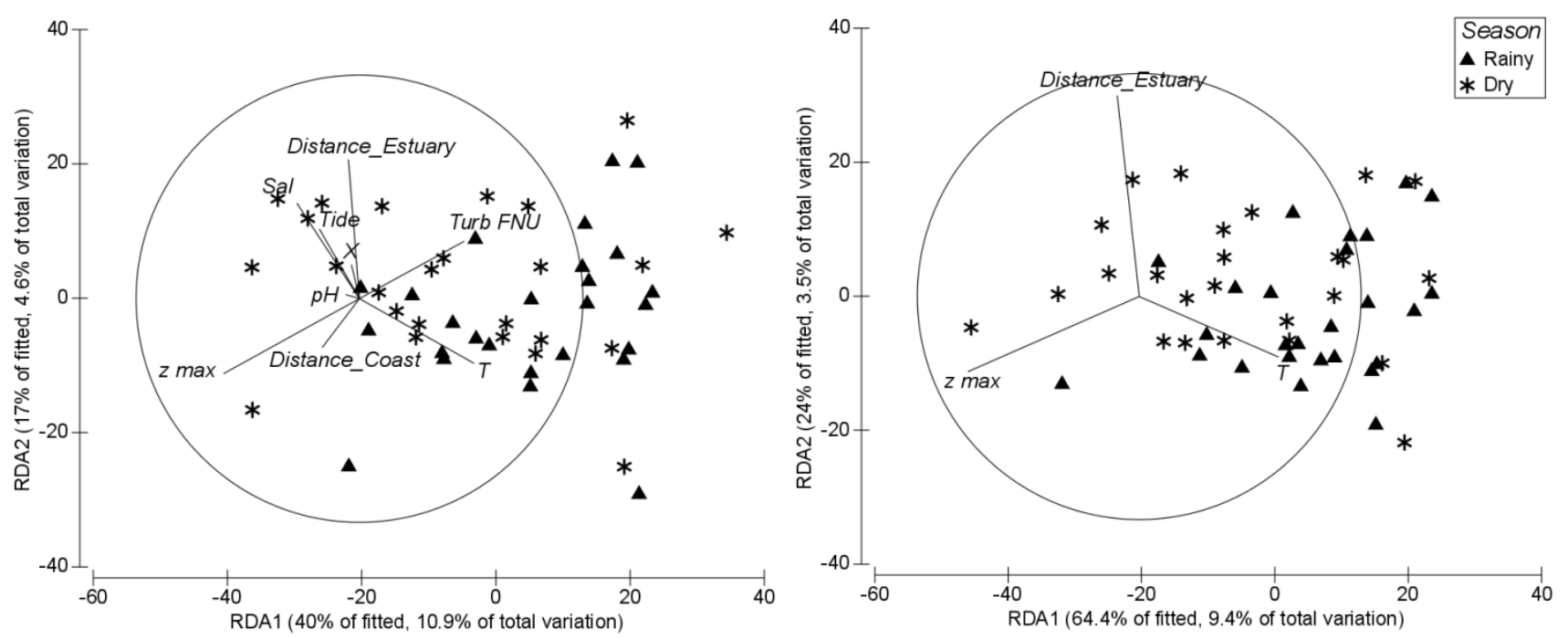

Figure 7. (a) Distance-based redundancy analysis (dbRDA) on the square root transformed species using the Bray-Curtis resemblance distance, with the normalised environmental and spatial variables as predictors. (b) dbRDA of the three significative environmental variables distance to the estuary, temperature and depth. 
This study is one of the first investigating the structure and dynamics of coastal fish populations of the inner shelf of French Guiana exploited by small-scale fisheries. Up to now, little was known about the factors influencing the distribution of demersal fish communities due to the lack of scientific fishing campaigns. Currently, even if bottom trawling remains one of the best ways to get representative samples of the demersal fish communities, trawls are not easy to use in the environmental context of the coastal area of French Guiana where mud banks colonise all the coastal nearshore grounds. Small trawls with small mesh size may be adapted with skates to avoid penetrating too deeply into the mud, but this reduces the probability of catching adult fish. Adapting larger and heavier trawls to mud banks seems less realistic. For these reasons, sampling was performed with drift nets operated as local small-scale coastal fisheries. Our results showed that despite a significant seasonal variability of the environmental parameters, coastal fishery communities in French Guiana are characterised by low seasonal variability and high spatial patchiness. Moreover, the dominant species are mostly estuarine and not strictly marine, suggesting that many native species may be living near to their biological tolerance limit (Kennedy, 1990; Odum, 1970; Roessig et al., 2004). Those communities are therefore particularly vulnerable in the face of environmental and climate changes, even though they tend to tolerate a higher range of variability in environmental conditions than typically freshwater or marine species (Pérez-Ruzafa et al., 2019).

A prerequisite for management and conservation of aquatic biodiversity is to fully understand the

341 local biodiversity and its changes in space and time. No unified method is employed and several 342 indexing, classification, ordination and multivariate techniques are commonly used (Lekve et al., 343 2005). Species accumulation curves are one of the methods which provide information about the species distribution of the studied community (Colwell and Coddington, 1994). Theoretically, the accumulation curve reaches an asymptote if an adequate number of samples are collected, in practice, the asymptote is often not reached even after a considerable sampling effort (Lekve et al., 
2005). In our large-scale study, we did not reach the asymptotic point and estimations suggest that

348 about $60 \%$ of the species were sampled. Species number found in our study ( 57 species for 55 samples) is however corroborated when compared with results from a coastal campaign in nearby Suriname (61 species in 95 trawl samples) (Willems et al., 2015b).

351

352

The dissimilarities between the sample-based and the individual-based rarefaction curves indicate an important spatial heterogeneity especially during the rainy season. The sample-based curves generally lie below the individual-based ones because they tend to aggregate individuals that are close either in time or in space (Gotelli and Colwell, 2001). While little seasonal difference was present in the sampling effort, a clear difference between rainy and dry season was evident in terms of individuals. For the same number of individuals sampled we have a difference of 5-10 species, with more species encountered during the dry season. This indicates that the difference is not due to a sampling bias, but rather to a biological meaningful pattern since differences between sample and individual rarefaction curves can be used as a measure of patchiness (Colwell and Coddington, 1994). Our results suggest that a higher patchiness was present during the rainy season probably due to some kind of aggregation behaviour for feeding or reproduction (Domeier and Colin, 1997; Johannes, 1978).

The high spatial patchiness found during our sampling was partly due to the presence of a high number of rare species (nearly $45 \%$ of the species occurred in less than $5 \%$ of the samples). Unfortunately, no detailed data on the habitats, currents and food availability are available for the studied area. Moreover, the extensive presence of mangrove nursery areas in proximity to the sampling site can promote the presence of migrating species and increase fish diversity. Several coastal and offshore fish species, including commercial ones, use mangrove and estuaries as a calm and nutritious nursery area for larvae and juveniles (Beck et al., 2001).

However, it should be considered that the presence of rare species and diversity patchiness could also be a consequence of the sampling method and the spatial grain employed. Some species may be 
able to avoid, or escape from the net and benthic species can accidentally be caught in some shallow areas. The characterisation of rare species as such needs therefore to be confirmed by a multi-gear study to increase the abundance accuracy, species detectability and lower biases (Zhou et al., 2014).

Despite the high spatial variability, little or no seasonal differences were present in the community composition even if environmental conditions were significantly different between the two seasons. The increase in freshwater runoffs from tropical rains causes lower salinities and the leaching of soils and rivers into nearby coastal waters induces a higher turbidity during the rainy season (Artigas et al., 2003). Important seasonal effects on fish assemblage have been shown in tropical estuarine systems, but deeper areas far from the land have a much greater volume of water and are therefore less influenced by seasonal changes (Barletta et al., 2003; Bradley et al., 2017; Passos et al., 2016). Nonetheless, the shelf ecosystem of French Guiana is a quasi-estuarine transitional environment where environmental conditions can vary importantly over time and space (Pérez-Ruzafa et al., 2011). These transitional environments, such as estuaries or lagoons, act as buffer zones between different habitats or migrating routes for fish species (Franco et al., 2006; Pérez-Ruzafa et al., 2011). The presence of several estuarine fish (such as Sciades proops, Bagre bagre, or Cynoscion acoupa) in our data set confirms the strong influence of freshwater input in the area. Estuarine species are eurytypical given their ability to tolerate large variations of salinity, temperature or turbidity. Salinity and turbidity have been shown to be a structuring factor of estuarine fish assemblages especially for larvae and juveniles (Barletta et al., 2005; Tito De Morais and Tito De Morais, 1994). Fish communities sampled in proximity to the estuaries gave results which were significantly different from the others and the distance from the coastline and estuaries were important factors explaining fish distribution and abundances. This demonstrates that local and regional estuaries have a major influence on the environmental conditions and fish distribution and the abundance of tropical coastal areas. 
The most abundant and widely distributed species recorded in this study was the crucifix sea catfish (Sciades proops). This coastal species inhabits estuaries and mudflats and is particularly adapted to warm, muddy and brackish waters (Leopold, 2005). A high tolerance to salinity and temperature, a particular reproductive behaviour and the presence of a complex hearing apparatus makes catfish the most successful group of fish from freshwater to the marine environment (Dantas et al., 2010). Their diet composed of mostly shrimps, as well as fish and other invertebrates with moderate influence of the season on the feeding regime, shows that they are an opportunistic species (Ton et al., 2016). The crucifix catfish, as many other catfish species in northeast Brazil, varies in density and biomass in correlation with salinity and dissolved oxygen, depending on the season (Barletta et al., 2010). S. proops is one of the most fished species in French Guiana, with 300 tons caught in 2017 (Observateurs du SIH, 2018a).

Together with S. proops, two other species showed a large distribution range; the coco sea catfish (Bagre bagre) and the green weakfish (Cynoscion virescens). Both species are common and abundant species not only in French Guiana waters but also in the Caribbean and Guiana shelf region, and down to the Amazon and northeast region of Brazil. Bagre bagre is considered to be anadromous and migrates towards estuaries during reproduction. Despite this species mainly feeds on fish and crustaceans, the feeding strategy is generalist (Pinheiro-Sousa et al., 2016; Tavares and Beneditto, 2017). Cynoscion virescens is an important predator living on muddy and sandy bottoms in coastal and estuarine ecosystems (Vergara-Chen et al., 2009). Despite their ecological and economic importance, little is known about their biology and data are often restricted to fishery campaigns (FAO/WECAFC, 2001). Both species are considered as "Least concern" by the IUCN red list, however their stock assessment is not available yet and Cynoscion virescens seems to suffer from overfishing pressure in the nearby Suriname (Charlier et al., 2000 in FAO/WECAFC, 2000).

Observation of some particularly interesting behaviour was recorded for the Atlantic tripletail (Lobotes surinamensis) that appeared in exceptionally high concentrations during the rainy season in 
proximity to estuarine outlets. Tripletail is a tropical and subtropical migratory species showing an

422 aggregation behaviour during spring and summer often targeted by anglers in the USA (Franks et al.,

423 2003; Parr, 2011; Strelcheck et al., 2004). This species is highly influenced by seasonality with a clear regime shift, based exclusively on fish during the dry season to a more opportunistic feeding regime (Strelcheck et al., 2004) with a diversification of crabs, shrimps and fish during the rainy season (Ton et al., 2016). It is also known that this species spawns offshore and becomes sexually mature during the rainy season (Franks et al., 2001; Strelcheck et al., 2004; Ton et al., 2016). Our results therefore reflect seasonal aggregation behaviour probably linked to some reproductive and possibly feeding strategies. Unfortunately, no data on the sexual developmental stage are available and further studies are needed to better understand this phenomenon in French Guiana waters. were carried out only during one dry and one rainy season so that no information on the inter-annual variability is available. It is well known that coastal communities are subject to important interannual changes affecting both species diversity and abundance (Selleslagh and Amara, 2008) as well as climate change which can only be studied in the long-term (Harley et al., 2006). A multi-annual study employing a similar protocol is then necessary to evaluate the inter-annual variability, as well as the effects of long-term environmental changes, on the French Guiana coastal fish communities (Magurran et al., 2010).

\section{Conclusions}

Tropical coastal ecosystems are facing increasing levels of pressure from a multitude of sources.

441 Unfortunately, very little is still known about fish community compositions and dynamics despite the 442 ecological and economical importance of those assemblages. This study underlined the importance of French Guiana coastal waters for its ability to sustain high fish abundances and diversity. The considerable spatial variability and the presence of several rare species make these communities highly susceptible to environmental changes and human pressure. 
446 To date, no regulations and management programs on fishing zones and capture size have been 447 implemented to regulate coastal fisheries in French Guiana. Despite regular recording of fish landings and some occasional onboard observation of discards (as much as $20 \%$ of the catches, pers. obs.), no monitoring programs on by-catch and discards are available. Considering the disproportionate vulnerability and importance of rare species to maintain ecological processes (Mouillot et al., 2013), a precautionary principle needs to be applied for the conservation of the ecosystem (Leitão et al., 2016). Our primary results suggest that coastal areas close to estuaries constitute important hotspots for both diversity and abundance which may host seasonal aggregative behaviour for important commercial species. We suggest that more data (such as sex, age, or other biological parameters) should be collected through monitoring programs and scientific fishing campaigns for a better understanding of French Guiana's species ecology and distribution. The implementation of a seasonal closure of fisheries in these hotspots could potentially help to reduce the pressure on reproductive and vulnerable species. This type of seasonal fishing closure has proven more effective than 459 complete closure in nearby Brazil (De Figueiredo Silva et al., 2012). Those management practices allow for a better control and a good balance between the sustainable use of the resource and the needs of local communities. need to account for these changes and develop adaptive strategies (Cinner et al., 2018). This is particularly important given the significant demographic growth of French Guiana. Currently, the coastal small-scale fisheries contribute substantially to the local economy, to the primary sector and to food security (Cissé et al., 2015, 2013), hence the importance of a better understanding of fish stocks in French Guiana. 
469 This work has been carried out with financial support from the European funds FEDER and SHELL. We 470 thank José Achille, fisherman and shipowner for the possibility to rent his boat for the sampling at

471 sea. We would also like to acknowledge L. Baulier, E. Mansuy, C. Ton and F. Grigoletto for data 472 collection and onboard species identification during the campaigns. Finally, we thank P. Le Joncour 473 and B.M. Diop for proofreading the manuscript. We appreciate and thank the reviewers for their 474 useful comments and suggestions to improve our manuscript. 
Anderson, M.J., 2001. A new method for non-parametric multivariate analysis of variance. Austral Ecol. 26, 32-46. https://doi.org/10.1111/j.1442-9993.2001.01070.pp.x

Anderson, M.J., Gorley, R.N., Clarke, K.R., 2008. PERMANOVA+ for PRIMER: Guide to Software and Statistical Methods. PRIMER-E, Plymouth, UK.

Anthony, E.J., Gardel, A., Gratiot, N., Proisy, C., Allison, M.A., Dolique, F., Fromard, F., 2010. The Amazon-influenced muddy coast of South America: A review of mud-bank-shoreline interactions. Earth-Sci. Rev. 103, 99-121. https://doi.org/10.1016/j.earscirev.2010.09.008

Anthony, E.J., Gardel, A., Proisy, C., Fromard, F., Gensac, E., Peron, C., Walcker, R., Lesourd, S., 2013. The role of fluvial sediment supply and river-mouth hydrology in the dynamics of the muddy, Amazon-dominated Amapá-Guianas coast, South America: A three-point research agenda. J. South Am. Earth Sci. 44, 18-24. https://doi.org/10.1016/j.jsames.2012.06.005

Artigas, L.F., Vendeville, P., Leopold, M., Guiral, D., Ternon, J.-F., 2003. Marine biodiversity in French Guiana: estuarine, coastal and shelf ecosystems under the influence of Amazonian waters. Gayana 67, 302-326. http://dx.doi.org/10.4067/S0717-65382003000200013.

Barbier, E.B., Hacker, S.D., Kennedy, C., Koch, E.W., Stier, A.C., Silliman, B.R., 2011. The value of estuarine and coastal ecosystem services. Ecol. Monogr. 81, 169-193. https://doi.org/10.1890/10-1510.1

Barletta, M., Barletta-Bergan, A., Saint-Paul, U., Hubold, G., 2005. The role of salinity in structuring the fish assemblages in a tropical estuary. J. Fish Biol. 66, 45-72. https://doi.org/10.1111/j.0022-1112.2005.00582.x

Barletta, M., Barletta-Bergan, A., Saint-Paul, U., Hubold, G., 2003. Seasonal changes in density, biomass, and diversity of estuarine fishes in tidal mangrove creeks of the lower Caeté Estuary (northern Brazilian coast, east Amazon). Mar. Ecol. Prog. Ser. 256, 217-228. https://doi.org/10.3354/meps256217

Barletta, M., Jaureguizar, A.J., Baigun, C., Fontoura, N.F., Agostinho, A.A., Almeida-Val, V.M.F. de, Val, A.L., Torres, R.A., Jimenes-Segura, L.F., Giarrizzo, T., 2010. Fish and aquatic habitat conservation in South America: a continental overview with emphasis on neotropical systems. J. Fish Biol. 76, 2118-2176. https://doi.org/10.1111/j.1095-8649.2010.02684.x

Beck, M.W., Heck, K.L., Able, K.W., Childers, D.L., Eggleston, D.B., Gillanders, B.M., Halpern, B., Hays, C.G., Hoshino, K., Minello, T.J., Orth, R.J., Sheridan, P.F., Weinstein, M.P., 2001. The Identification, Conservation, and Management of Estuarine and Marine Nurseries for Fish and Invertebrates. BioScience 51, 633-641. https://doi.org/10.1641/00063568(2001)051[0633:TICAMO]2.0.CO;2

Behrenfeld, M.J., O'Malley, R.T., Siegel, D.A., McClain, C.R., Sarmiento, J.L., Feldman, G.C., Milligan, A.J., Falkowski, P.G., Letelier, R.M., Boss, E.S., 2006. Climate-driven trends in contemporary ocean productivity. Nature 444, 752-755. https://doi.org/10.1038/nature05317

Bernard, C., 2006. Changement climatique, conséquences potentielles pour la biodiversité ichthyologique et pour la pêche côtière en Guyane française entre 1970 et 2005. (Mémoire Master 2 Geni.A.L Université La Rochelle). Ifremer, Cayenne, Guyane.

Blaber, S.J.M., 2002. "Fish in hot water": the challenges facing fish and fisheries research in tropical estuaries. J. Fish Biol. 61, 1-20. https://doi.org/10.1111/j.1095-8649.2002.tb01757.x

Blaber, S.J.M., 2000. Effects of fishing on the structure and functioning of estuarine and nearshore ecosystems. ICES J. Mar. Sci. 57, 590-602. https://doi.org/10.1006/jmsc.2000.0723

Botsford, L.W., Castilla, J.C., Peterson, C.H., 1997. The Management of Fisheries and Marine Ecosystems. Science 277, 509-515. https://doi.org/10.1126/science.277.5325.509

Bradley, M., Baker, R., Sheaves, M., 2017. Hidden Components in Tropical Seascapes: Deep-Estuary Habitats Support Unique Fish Assemblages. Estuaries Coasts 40, 1195-1206. https://doi.org/10.1007/s12237-016-0192-z

Camara, M., Mérigot, B., Leprieur, F., Tomasini, J., Diallo, I., Diallo, M., Jouffre, D., 2016. Structure and dynamics of demersal fish assemblages over three decades (1985-2012) of increasing 
fishing pressure in Guinea. Afr. J. Mar. Sci. 38, 189-206. https://doi.org/10.2989/1814232X.2016.1179219

Charbonnel, E., Francour, P., Harmelin, J.G., Ody, D., 1995. Les problèmes d'échantillonnage et de recensement du peuplement ichtyologique dans les récifs artificiels. Biol. Mar. Mediterr. 2, 85-90.

Cinner, J.E., Adger, W.N., Allison, E.H., Barnes, M.L., Brown, K., Cohen, P.J., Gelcich, S., Hicks, C.C., Hughes, T.P., Lau, J., Marshall, N.A., Morrison, T.H., 2018. Building adaptive capacity to climate change in tropical coastal communities | Nature Climate Change. Nat. Clim. Change 8, 117-123. https://doi.org/10.1038/s41558-017-0065-x

Cissé, A.A., Blanchard, F., Guyader, O., 2014. Sustainability of tropical small-scale fisheries: Integrated assessment in French Guiana. Mar. Policy 44, 397-405. https://doi.org/10.1016/j.marpol.2013.10.003

Cissé, A.A., Doyen, L., Blanchard, F., Béné, C., Péreau, J.-C., 2015. Ecoviability for small-scale fisheries in the context of food security constraints. Ecol. Econ. 119, 39-52. https://doi.org/10.1016/j.ecolecon.2015.02.005

Cissé, A.A., Gourguet, S., Doyen, L., Blanchard, F., Péreau, J.-C., 2013. A bio-economic model for the ecosystem-based management of the coastal fishery in French Guiana. Environ. Dev. Econ. 18, 245-269. https://doi.org/10.1017/S1355770X13000065

Clarke, K.R., Gorley, R.N., 2015. PRIMER v7: User Manual/Tutorial. PRIMER-E, Plymouth, UK.

Colwell, R.K., Coddington, J.A., 1994. Estimating terrestrial biodiversity through extrapolation. Philos. Trans. R. Soc. Lond. B. Biol. Sci. 345, 101-118. https://doi.org/10.1098/rstb.1994.0091

Dantas, D.V., Barletta, M., Costa, M.F., Barbosa-Cintra, S.C.T., Possatto, F.E., Ramos, J. a. A., Lima, A.R.A., Saint-Paul, U., 2010. Movement patterns of catfishes (Ariidae) in a tropical semi-arid estuary. J. Fish Biol. 76, 2540-2557. https://doi.org/10.1111/j.1095-8649.2010.02646.x

De Figueiredo Silva, S.L., Camargo, M., Estupiñan, R.A., 2012. Fishery management in a conservation area. The case of the Oiapoque River in northern Brazil. CYBIUM, Fishes of the Guianas: scientific advances and future prospects for a highly diversified fauna 36, 17-30.

Dengler, J., 2009. Which function describes the species-area relationship best? A review and empirical evaluation. J. Biogeogr. 36, 728-744. https://doi.org/10.1111/j.13652699.2008.02038.x

Diop, B., Blanchard, F., Sanz, N., 2018a. Mangrove increases resiliency of the French Guiana shrimp fishery facing global warming. Ecol. Model. 387, 27-37. https://doi.org/10.1016/j.ecolmodel.2018.08.014

Diop, B., Sanz, N., Blanchard, F., Walcker, R., Gardel, A., 2018b. The role of mangrove in the French Guiana shrimp fishery. J. Environ. Econ. Policy 1-12. https://doi.org/10.1080/21606544.2018.1522601

Diop, B., Sanz, N., Duplan, Y.J.J., Guene, E.H.M., Blanchard, F., Pereau, J.-C., Doyen, L., 2018c. Maximum Economic Yield Fishery Management in the Face of Global Warming. Ecol. Econ. 154, 52-61. https://doi.org/10.1016/j.ecolecon.2018.07.027

Domeier, M.L., Colin, P.L., 1997. Tropical Reef Fish Spawning Aggregations: Defined and Reviewed. Bull. Mar. Sci. 60, 698-726.

Durand, J., 1959. Notes sur le plateau continental Guyanais: Les éléments principaux de la faune et leurs relations avec le fond (No. 3), Cahiers de l'ORSTOM. ORSTOM, Paris, France.

FAO/WECAFC, 2001. Regional Reviews and National Management Reports: The Fourth Workshop on the Assessment and Management of Shrimp and Groundfish Fisheries on the Brazil-Guianas Shelf, Cumaná, Venezuela, 2-13 October 2000 (FAO Fisheries Report No. 651). Food \& Agriculture Org., Rome, Italie.

FAO/WECAFC, 2000. Report of the third workshop on the assessment of shrimp and groundfish fisheries on the Brazil-Guianas shelf. Belém, Brazil, 24 May - 10 June 1999. (FAO Fisheries Report No. 628). Food \& Agriculture Org., Rome, Italie. 
Franco, A., Franzoi, P., Malavasi, S., Riccato, F., Torricelli, P. (Eds.), 2006. Fish assemblages in different shallow water habitats of the Venice Lagoon. Hydrobiologia 555, 159-174. https://doi.org/10.1007/s10750-005-1113-5

Franks, J.S., Ogle, J.T., Hendon, J.R., Barnes, D.N., Nicholson, L.C., 2001. Growth of Captive Juvenile Tripletail Lobotes surinamensis. Gulf Caribb. Res. 13, 67-70. https://doi.org/10.18785/gcr.1301.07

Franks, J.S., VanderKooy, K.E., Garber, N.M., 2003. Diet of Tripletail, Lobotes surinamensis, from Mississippi Coastal Waters. Gulf Caribb. Res. 15, 27-32. https://doi.org/10.18785/gcr.1501.05

Froese, R., Pauly, D., 2019. FishBase, World Wide Web electronic publication.

Froidefond, J.-M., Gardel, L., Guiral, D., Parra, M., Ternon, J.-F., 2002. Spectral remote sensing reflectances of coastal waters in French Guiana under the Amazon influence. Remote Sens. Environ. 80, 225-232. https://doi.org/10.1016/S0034-4257(01)00301-7

Froidefond, J.M., Lahet, F., Hu, C., Doxaran, D., Guiral, D., Prost, M.T., Ternon, J.-F., 2004. Mudflats and mud suspension observed from satellite data in French Guiana. Mar. Geol. 208, 153-168. https://doi.org/10.1016/j.margeo.2004.04.025

Gotelli, N.J., Colwell, R.K., 2001. Quantifying biodiversity: procedures and pitfalls in the measurement and comparison of species richness. Ecol. Lett. 4, 379-391. https://doi.org/10.1046/j.14610248.2001.00230.x

Gratiot, N., Gardel, A., Polidori, L., 2005. Remote sensing based bathymetry on the highly dynamic amazonian coast, in: Proceedings of the 9th International Coastal Symposium. Presented at the 9th International Coastal Symposium, Iceland, p. 13.

Harley, C.D.G., Hughes, A.R., Hultgren, K.M., Miner, B.G., Sorte, C.J.B., Thornber, C.S., Rodriguez, L.F., Tomanek, L., Williams, S.L., 2006. The impacts of climate change in coastal marine systems. Ecol. Lett. 9, 228-241. https://doi.org/10.1111/j.1461-0248.2005.00871.x

Hoegh-Guldberg, O., Bruno, J.F., 2010. The Impact of Climate Change on the World's Marine Ecosystems. Science 328, 1523-1528. https://doi.org/10.1126/science.1189930

Hu, C., Montgomery, E.T., Schmitt, R.W., Muller-Karger, F.E., 2004. The dispersal of the Amazon and Orinoco River water in the tropical Atlantic and Caribbean Sea: Observation from space and S-PALACE floats. Deep Sea Res. Part II Top. Stud. Oceanogr. 51, 1151-1171. https://doi.org/10.1016/j.dsr2.2004.04.001

Hutchings, J.A., Reynolds, J.D., 2004. Marine Fish Population Collapses: Consequences for Recovery and Extinction Risk. BioScience 54, 297-309. https://doi.org/10.1641/00063568(2004)054[0297:MFPCCF]2.0.CO;2

IEDOM, 2018. Rapport annuel IEDOM Guyane 2017. Institut d'Emission des Départements d'OutreMer (IEDOM), Paris, France.

Johannes, R.E., 1978. Reproductive strategies of coastal marine fishes in the tropics. Environ. Biol. Fishes 3, 65-84. https://doi.org/10.1007/BF00006309

Jost, L., 2006. Entropy and diversity. Oikos 113, 363-375. https://doi.org/10.1111/j.2006.00301299.14714.x

Jourde, J., Dupuy, C., Nguyen, H.T., Mizrahi, D., de Pracontal, N., Bocher, P., 2017. Low Benthic Macrofauna Diversity in Dynamic, Tropical Tidal Mudflats: Migrating Banks on Guiana's Coast, South America. Estuaries Coasts 40, 1159-1170. https://doi.org/10.1007/s12237-0160205-y

Kennedy, V.S., 1990. Anticipated Effects of Climate Change on Estuarine and Coastal Fisheries. Fisheries 15, 16-24. https://doi.org/10.1577/1548-8446(1990)015<0016:AEOCCO>2.0.CO;2

Lampert, L., 2013. Etude de la crise de la pêche de la crevette en Guyane (Rapport intermédiaire du Marché DPMA 2012-2021 : Etude portant sur l'effet du changement climatique et/ou du réseau trophique sur le stock guyanais de crevettes pénéïdes No. RBE/BIODIVHAL 2013-2). Ifremer, Cayenne, Guyane. 
Legendre, P., Anderson, M.J., 1999. Distance-Based Redundancy Analysis: Testing Multispecies Responses in Multifactorial Ecological Experiments. Ecol. Monogr. 69, 1. https://doi.org/10.2307/2657192

Legendre, P., Blanchet, G., 2015. T-Paired-Perm function in R.

Leitão, R.P., Zuanon, J., Villéger, S., Williams, S.E., Baraloto, C., Fortunel, C., Mendonça, F.P., Mouillot, D., 2016. Rare species contribute disproportionately to the functional structure of species assemblages. Proc. R. Soc. B Biol. Sci. 283, 20160084. https://doi.org/10.1098/rspb.2016.0084

Lekve, K., Ellingsen, K.E., Lingjærde, O.Chr., Gjøsæter, J., Stenseth, N.Chr., 2005. Spatio-temporal variability of richness estimators: coastal marine fish communities as examples. Oecologia 144, 308-317. https://doi.org/10.1007/s00442-005-0049-9

Leopold, M., 2005. Poissons de mer de Guyane - Guide illustré, Ifremer. ed. IFREMER / DIREN GUYANE / FEDER.

Lomolino, M.V., 2000. Ecology's most general, yet protean pattern: The species-area relationship. J. Biogeogr. 27, 17-26. https://doi.org/10.1046/j.1365-2699.2000.00377.x

Lowe-McConnell, R.H. (Ed.), 1987. Demersal fish studies, in: Ecological Studies in Tropical Fish Communities, Cambridge Tropical Biology Series. Cambridge University Press, Cambridge, p. 382. https://doi.org/10.1017/CBO9780511721892.010

Magurran, A.E., Baillie, S.R., Buckland, S.T., Dick, J.McP., Elston, D.A., Scott, E.M., Smith, R.I., Somerfield, P.J., Watt, A.D., 2010. Long-term datasets in biodiversity research and monitoring: assessing change in ecological communities through time. Trends Ecol. Evol. 25, 574-582. https://doi.org/10.1016/j.tree.2010.06.016

Maravelias, C.D., 2001. Habitat associations of Atlantic herring in the Shetland area: influence of spatial scale and geographic segmentation. Fish. Oceanogr. 10, 259-267. https://doi.org/10.1046/j.1365-2419.2001.00172.x

Mouillot, D., Bellwood, D.R., Baraloto, C., Chave, J., Galzin, R., Harmelin-Vivien, M., Kulbicki, M., Lavergne, S., Lavorel, S., Mouquet, N., Paine, C.E.T., Renaud, J., Thuiller, W., 2013. Rare Species Support Vulnerable Functions in High-Diversity Ecosystems. PLoS Biol. 11. https://doi.org/10.1371/journal.pbio.1001569

Nittrouer, C.A., Brunskill, G.J., Figueiredo, A.G., 1995. Importance of tropical coastal environments. Geo-Mar. Lett. 15, 121-126. https://doi.org/10.1007/BF01204452

Observateurs du SIH, 2018a. Rapport ObsDEB: Estimation 2017 des efforts de pêche et des productions dans les régions Méditerranée continentale, La Réunion, Martinique, Guadeloupe et Guyane. (Rapport annuel Convention DPMA-Ifremer 2018). Ifremer, Brest, France.

Observateurs du SIH, 2018b. Situation de la pêche en Guyane en 2016. Ifremer, Brest, France.

Observateurs du SIH, 2017. Situation de la pêche en Guyane en 2015. Ifremer, Brest, France.

Observateurs du SIH, 2016. Situation de la pêche en Guyane en 2014. Ifremer, Brest, France.

Observateurs du SIH, 2014. Situation de la pêche en Guyane en 2013. Ifremer, Brest, France.

Odum, W.E., 1970. Insidious Alteration of the Estuarine Environment. Trans. Am. Fish. Soc. 99, 836847. https://doi.org/10.1577/1548-8659(1970)99<836:IAOTEE>2.0.CO;2

Oksanen, J., Blanchet, F.G., Kindt, R., Legendre, P., O'hara, R.B., Simpson, G.L., Solymos, P., Stevens, M.H.H., Wagner, H., 2010. Vegan: community ecology package. R package version 1.17-4. Httpcran R-Proj. Org Acesso Em 23, 2010.

Parr, R.T., 2011. Age, growth, and reproductive status of tripletail (Lobotes surinamensis) in the aggregation nearshore Jekyll Island, GA, USA (Master of Science Thesis). University of Georgia, Athens, Greece.

Passos, C.V.B., Fabré, N.N., Malhado, A.C.M., Batista, V.S., Ladle, R.J., 2016. Estuarization increases functional diversity of demersal fish assemblages in tropical coastal ecosystems: estuarization and functional diversity. J. Fish Biol. 89, 847-862. https://doi.org/10.1111/jfb.13029 
Pérez-Ruzafa, A., Marcos, C., Pérez-Ruzafa, I.M., Pérez-Marcos, M., 2011. Coastal lagoons: "transitional ecosystems" between transitional and coastal waters. J. Coast. Conserv. 15, 369-392. https://doi.org/10.1007/s11852-010-0095-2

Pérez-Ruzafa, A., Pérez-Ruzafa, I.M., Newton, A., Marcos, C., 2019. Coastal Lagoons: Environmental Variability, Ecosystem Complexity, and Goods and Services Uniformity, in: Coasts and Estuaries. Elsevier, pp. 253-276. https://doi.org/10.1016/B978-0-12-814003-1.00015-0

Perry, A.L., 2005. Climate Change and Distribution Shifts in Marine Fishes. Science 308, 1912-1915. https://doi.org/10.1126/science.1111322

Pielou, E.C., 1966. Species-diversity and pattern-diversity in the study of ecological succession. J. Theor. Biol. 10, 370-383. https://doi.org/10.1016/0022-5193(66)90133-0

Pinheiro-Sousa, D.B., Silva, N.K. da, Pioski, N.M., Rocha, A.C.G., Carvalho-Neta, R.N.F., Almeida, Z. da S. de, 2016. Aspectos alimentares e reproductivos de Bagre bagre (Pisces, Ariidae) em um estuario da Ilha de São Luis, Maranhão, Brasil. Rev. Bras. Eng. Pesca 8, 01-12. https://doi.org/10.18817/repesca.v8i2.1097

Poulard, J., Blanchard, F., 2005. The impact of climate change on the fish community structure of the eastern continental shelf of the Bay of Biscay. ICES J. Mar. Sci. 62, 1436-1443. https://doi.org/10.1016/j.icesjms.2005.04.017

QGIS Development Team, 2018. QGIS Geographic Information System. Open Source Geospatial Foundation Project.

R Core Team, 2017. R: A language and environment for statistical computing. R Foundation for Statistical Computing, Vienna, Austria.

Rivierre, A., 2007. Impact des changements climatiques et de la pêche sur les peuplements benthopélagiques du plateau continental guyanais. (No. HMT/RHGUYANE 2007-04). Ifremer, Cayenne, Guyane.

Roessig, J.M., Woodley, C.M., Cech, J.J., Hansen, L.J., 2004. Effects of global climate change on marine and estuarine fishes and fisheries. Rev. Fish Biol. Fish. 14, 251-275. https://doi.org/10.1007/s11160-004-6749-0

Rousseau, Y., Blanchard, F., Gardel, A., 2018. Spatiotemporal dynamics of larval fish in a tropical estuarine mangrove: example of the Mahury River Estuary (French Guiana). Can. J. Fish. Aquat. Sci. 75, 235-246. https://doi.org/10.1139/cjfas-2016-0267

Salas, S., Chuenpagdee, R., Seijo, J.C., Charles, A., 2007. Challenges in the assessment and management of small-scale fisheries in Latin America and the Caribbean. Fish. Res., Evaluation and Management of Coastal Fisheries in Latin America and the Caribbean 87, 516. https://doi.org/10.1016/j.fishres.2007.06.015

Sanz, N., Diop, B., Blanchard, F., Lampert, L., 2017. On the influence of environmental factors on harvest: the French Guiana shrimp fishery paradox. Environ. Econ. Policy Stud. 19, 233-247. https://doi.org/10.1007/s10018-016-0153-6

Selleslagh, J., Amara, R., 2008. Inter-season and interannual variations in fish and macrocrustacean community structure on a eastern English Channel sandy beach: Influence of environmental factors. Estuar. Coast. Shelf Sci. 77, 721-730. https://doi.org/10.1016/j.ecss.2007.11.004

Shannon, C.E., 1948. A Mathematical Theory of Communication. Bell Syst. Tech. J. 27, 379-423. https://doi.org/10.1002/j.1538-7305.1948.tb01338.x

Strelcheck, A.J., Jackson, J.B., Cowan, J.H., Shipp, R.L., 2004. Age, Growth, Diet, and Reproductive Biology of the Tripletail, Lobotes surinamensis, From the North-Central Gulf of Mexico. Gulf Mex. Sci. 22, 45-53. https://doi.org/10.18785/goms.2201.04

Tavares, M.T.M., Beneditto, A.P.M.D., 2017. Feeding habits and behaviour of Bagre bagre and Genidens barbus, two ariid catfishes (Pisces: Siluriformes) from southeastern Brazil. J. Threat. Taxa 9, 10771-10775. https://doi.org/10.11609/jott.3758.9.10.10771-10775

Tessier, E., Chabanet, P., Pothin, K., Soria, M., Lasserre, G., 2005. Visual censuses of tropical fish aggregations on artificial reefs: slate versus video recording techniques. J. Exp. Mar. Biol. Ecol. 315, 17-30. https://doi.org/10.1016/j.jembe.2004.08.027 
Tito De Morais, A., Tito De Morais, L., 1994. The abundance and diversity of larval and juvenile fish in a tropical estuary. Estuaries 17, 216-225. https://doi.org/10.2307/1352571

Ton, C., Magraoui, A., Blanchard, F., Baulier, L., Andre, H., Grigoletto, F., Mansuy, E., 2016. Structure et dynamique de la biodiversité halieutique dans les eaux guyanaises - Projet STUDY Rapport Final (No. Ref: 572/2014/BSF/CJ, Feder Présage $n^{\circ}$ 32042), R.INT.RBE/BIODIVHAL/2016-1. Ifremer, Cayenne, Guyane.

Travers, M., Shin, Y.-J., Jennings, S., Cury, P., 2007. Towards end-to-end models for investigating the effects of climate and fishing in marine ecosystems. Prog. Oceanogr. 75, 751-770. https://doi.org/10.1016/j.pocean.2007.08.001

Vendeville, P., Baudrier, J., 2006. Etude des peuplements de juvéniles de poissons et de crevettes des fonds du littoral de Guyane (Rapport final No. 03/12/1214788/F). Ifremer, Centre de Méditerranée Département Halieutique Méditerranéenne et Tropicale Station de Guyane Laboratoire Ressources Halieutiques de Guyane.

Vergara-Chen, C., Aguirre, W.E., González-Wangüemert, M., Bermingham, E., 2009. A mitochondrial DNA based phylogeny of weakfish species of the Cynoscion group (Pisces: Sciaenidae). Mol. Phylogenet. Evol. 53, 602-607. https://doi.org/10.1016/j.ympev.2009.06.013

Ware, D.M., 2005. Bottom-Up Ecosystem Trophic Dynamics Determine Fish Production in the Northeast Pacific. Science 308, 1280-1284. https://doi.org/10.1126/science.1109049

Willems, T., De Backer, A., Mol, J.H., Vincx, M., Hostens, K., 2015a. Distribution patterns of the demersal fish fauna on the inner continental shelf of Suriname. Reg. Stud. Mar. Sci. 2, 177188. https://doi.org/10.1016/j.rsma.2015.10.008

Willems, T., De Backer, A., Mol, J.H., Vincx, M., Hostens, K., 2015b. Distribution patterns of the demersal fish fauna on the inner continental shelf of Suriname. Reg. Stud. Mar. Sci. 2, 177188. https://doi.org/10.1016/j.rsma.2015.10.008

Yemane, D., Field, J.G., Leslie, R.W., 2010. Spatio-temporal patterns in the diversity of demersal fish communities off the south coast of South Africa. Mar. Biol. 157, 269-281. https://doi.org/10.1007/s00227-009-1314-y

Zhou, S., Klaer, N.L., Daley, R.M., Zhu, Z., Fuller, M., Smith, A.D.M., 2014. Modelling multiple fishing gear efficiencies and abundance for aggregated populations using fishery or survey data. ICES J. Mar. Sci. 71, 2436-2447. https://doi.org/10.1093/icesjms/fsu068 
760 Table A.1. Location (GPS bearings in decimal degree), name and depth (in meters) of the stations

761 sampled during the two coastal campaigns carried out in French Guiana during the rainy and dry

762 season in 2015.

\begin{tabular}{|c|c|c|c|c|c|}
\hline Number & Season & Station & Latitude & Longitude & Depth \\
\hline 1 & Rainy & GY1D1 & -51.75117 & 4.56833 & 3.37 \\
\hline 2 & Rainy & GY1D2 & -51.64000 & 4.60200 & 6.38 \\
\hline 3 & Rainy & GY1D3 & -51.95683 & 4.67017 & 3.94 \\
\hline 4 & Rainy & GY1DExtra & -51.90517 & 4.76850 & 4.38 \\
\hline 5 & Rainy & GY2D12 & -52.03867 & 4.85500 & 7.86 \\
\hline 6 & Rainy & GY2D13 & -51.98300 & 4.79017 & 5.84 \\
\hline 7 & Rainy & GY2D21 & -52.34333 & 5.00800 & 4.77 \\
\hline 8 & Rainy & GY2D22 & -52.23633 & 4.98267 & 7.92 \\
\hline 9 & Rainy & GY2D23 & -52.24150 & 5.01067 & 9.06 \\
\hline 10 & Rainy & GY2D31 & -52.45383 & 5.09417 & 3.51 \\
\hline 11 & Rainy & GY2D32 & -52.52500 & 5.21861 & 6.64 \\
\hline 12 & Rainy & GY2D33 & -52.51333 & 5.14467 & 1.90 \\
\hline 13 & Rainy & GY3D11 & -52.65194 & 5.29972 & 8.64 \\
\hline 14 & Rainy & GY3D12 & -52.70583 & 5.32167 & 4.43 \\
\hline 15 & Rainy & GY3D13 & -52.76083 & 5.34056 & 2.57 \\
\hline 16 & Rainy & GY3D1Extra & -52.72278 & 5.37472 & 6.09 \\
\hline 17 & Rainy & GY3D21 & -53.06389 & 5.53389 & 2.08 \\
\hline 18 & Rainy & GY3D22 & -52.94056 & 5.49306 & 6.22 \\
\hline 19 & Rainy & GY3D23 & -52.97500 & 5.53639 & 5.24 \\
\hline 20 & Rainy & GY3D2Extra & -52.99111 & 5.52111 & 3.65 \\
\hline 21 & Rainy & GY4D11 & -53.21000 & 5.58917 & 2.84 \\
\hline 22 & Rainy & GY4D12 & -53.29500 & 5.62056 & 5.30 \\
\hline 23 & Rainy & GY4D13 & -53.50389 & 5.60556 & 1.98 \\
\hline 24 & Rainy & GY4D21 & -53.61583 & 5.72472 & 9.75 \\
\hline 25 & Rainy & GY4D22 & -53.79944 & 5.75222 & 3.27 \\
\hline 26 & Rainy & GY4D23 & -53.84139 & 5.88611 & 13.23 \\
\hline Number & Season & Station & Latitude & Longitude & Depth \\
\hline 1 & Dry & GY1D1 & $-51,75333$ & 4,56778 & 4.37 \\
\hline 2 & Dry & GY1D2 & $-51,64528$ & 4,60389 & 5.97 \\
\hline 3 & Dry & GY1D3 & $-51,96389$ & 4,67139 & 4.00 \\
\hline 4 & Dry & GY2D11 & $-52,12306$ & 4,89556 & NA \\
\hline 5 & Dry & GY2D12 & $-52,03611$ & 4,85528 & 7.88 \\
\hline 6 & Dry & GY2D13 & $-51,98472$ & 4,79472 & NA \\
\hline 7 & Dry & GY2D1Extra & $-52,07889$ & 4,89361 & NA \\
\hline 8 & Dry & GY2D21 & $-52,34806$ & 5,01278 & 4.44 \\
\hline 9 & Dry & GY2D22 & $-52,23972$ & 4,98472 & 6.90 \\
\hline
\end{tabular}




\begin{tabular}{rllllr}
\hline 10 & Dry & GY2D23 & $-52,24444$ & 5,01611 & 4.52 \\
11 & Dry & GY2D31 & $-52,45611$ & 5,09667 & 4.56 \\
12 & Dry & GY2D32 & $-52,52611$ & 5,21944 & 8.78 \\
13 & Dry & GY2D33 & $-52,51333$ & 5,14472 & 2.22 \\
14 & Dry & GY2D3Extra & $-52,57917$ & 5,19056 & 6.07 \\
15 & Dry & GY3D11 & $-52,65306$ & 5,30167 & 7.40 \\
16 & Dry & GY3D12 & $-52,70583$ & 5,32167 & 5.86 \\
17 & Dry & GY3D13 & $-52,76083$ & 5,34056 & 2.99 \\
18 & Dry & GY3D1Extra & $-52,72389$ & 5,38028 & 7.91 \\
19 & Dry & GY3D21 & $-53,05583$ & 5,54806 & 0.90 \\
20 & Dry & GY3D22 & $-52,94417$ & 5,49944 & 5.90 \\
21 & Dry & GY3D2Extra & $-52,99667$ & 5,52139 & 4.29 \\
22 & Dry & GY4D11 & $-53,21194$ & 5,58528 & NA \\
23 & Dry & GY4D12 & $-53,29472$ & 5,62639 & 7.17 \\
24 & Dry & GY4D13 & $-53,50833$ & 5,66861 & 6.69 \\
25 & Dry & GY4D1Extra & $-53,36528$ & 5,64722 & 6.65 \\
26 & Dry & GY4D21 & $-53,61500$ & 5,73167 & 2.25 \\
27 & Dry & GY4D22 & $-53,80056$ & 5,75222 & 2.75 \\
28 & Dry & GY4D23 & $-53,84583$ & 5,88722 & 12.80 \\
29 & Dry & GY4D2Extra & $-53,87111$ & 5,81417 & 4.43 \\
\hline
\end{tabular}




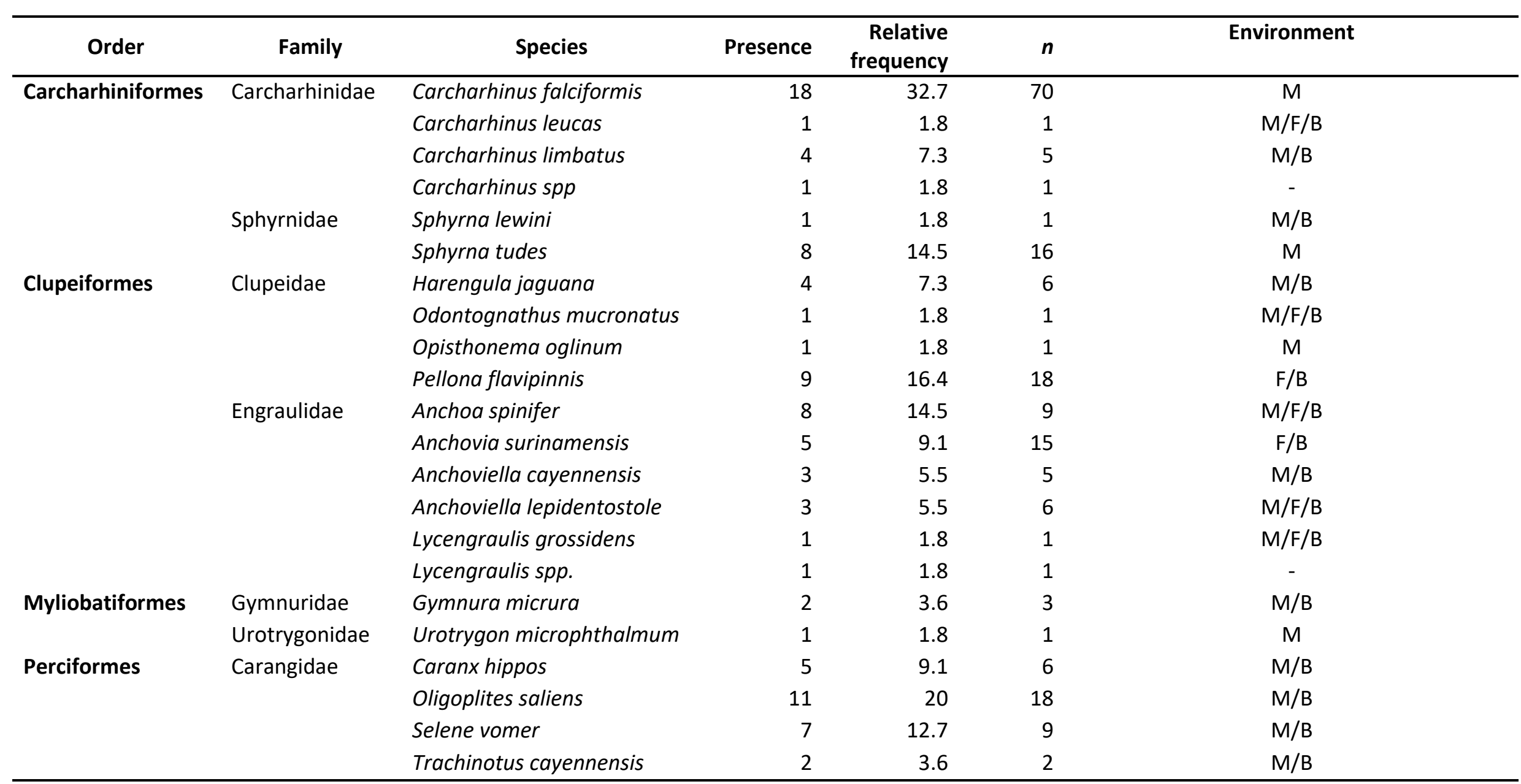




\begin{tabular}{|c|c|c|c|c|c|c|}
\hline \multirow{2}{*}{\multicolumn{2}{|c|}{ Centropomidae }} & Centropomus ensiferus & 2 & 3.6 & 2 & $\mathrm{M} / \mathrm{F} / \mathrm{B}$ \\
\hline & & Centropomus undecimalis & 1 & 1.8 & 1 & $M / F / B$ \\
\hline & Haemulidae & Genyatremus luteus & 15 & 27.3 & 29 & $M / B$ \\
\hline & Mugilidae & Mugil cephalus & 1 & 1.8 & 3 & $M / F / B$ \\
\hline & Sciaenidae & Cynoscion acoupa & 22 & 40 & 37 & $\mathrm{M} / \mathrm{F} / \mathrm{B}$ \\
\hline & & Cynoscion jamaicensis & 1 & 1.8 & 1 & $\mathrm{M} / \mathrm{B}$ \\
\hline & & Cynoscion steindachneri & 4 & 7.3 & 4 & $\mathrm{M} / \mathrm{F} / \mathrm{B}$ \\
\hline & & Cynoscion virescens & 28 & 50.9 & 92 & $M / B$ \\
\hline & & Lonchurus lanceolatus & 2 & 3.6 & 2 & $M / B$ \\
\hline & & Macrodon ancylodon & 19 & 34.5 & 37 & $\mathrm{M} / \mathrm{B}$ \\
\hline & & Micropogonias furnieri & 25 & 45.5 & 136 & $\mathrm{M} / \mathrm{B}$ \\
\hline & & Scomberomorus cavalla & 1 & 1.8 & 1 & $M$ \\
\hline & Stromateidae & Peprilus paru & 3 & 5.5 & 4 & $M / B$ \\
\hline Pleuronectiformes & Achiridae & Achirus achirus & 7 & 12.7 & 13 & $\mathrm{M} / \mathrm{F} / \mathrm{B}$ \\
\hline \multirow[t]{2}{*}{ Rajiformes } & Dasyatidae & Hypanus guttatus & 11 & 20 & 14 & M \\
\hline & Myliobatidae & Rhinoptera bonasus & 11 & 20 & 18 & $M / B$ \\
\hline \multirow[t]{6}{*}{ Siluriformes } & Ariidae & Amphiarius phrygiatus & 1 & 1.8 & 1 & $\mathrm{M} / \mathrm{B}$ \\
\hline & & Amphiarius rugispinis & 3 & 5.5 & 10 & $M / B$ \\
\hline & & Aspistor quadriscutis & 19 & 34.5 & 34 & $\mathrm{M} / \mathrm{F} / \mathrm{B}$ \\
\hline & & Bagre bagre & 28 & 50.9 & 65 & $M / B$ \\
\hline & & Notarius grandicassis & 3 & 5.5 & 4 & $M / B$ \\
\hline & & Sciades couma & 15 & 27.3 & 35 & $\mathrm{~F} / \mathrm{B}$ \\
\hline
\end{tabular}




\begin{tabular}{|c|c|c|c|c|c|c|}
\hline & & Sciades passany & 1 & 1.8 & 2 & $M / B$ \\
\hline & & Sciades proops & 46 & 83.6 & 331 & $M / F / B$ \\
\hline & Auchenipteridae & Pseudauchenipterus nodosus & 7 & 12.7 & 24 & $\mathrm{~F} / \mathrm{B}$ \\
\hline Total & & & & & 1807 & \\
\hline
\end{tabular}


Table A.3. Mean, standard deviation (SD), minimum and maximum of the environmental parameters used in this study.

\begin{tabular}{|c|c|c|c|c|c|c|c|c|}
\hline & \multicolumn{4}{|c|}{ Dry } & \multicolumn{4}{|c|}{ Rainy } \\
\hline & Mean & SD & Min & Max & Mean & SD & Min & Max \\
\hline Salinity & 33.504 & 2.162 & 25.843 & 34.962 & 31.094 & 4.413 & 17.088 & 35.442 \\
\hline$Z \max$ & 5.508 & 2.525 & 0.893 & 12.802 & 5.417 & 2.754 & 1.898 & 13.225 \\
\hline Turbidity & 60.765 & 86.143 & 2.442 & 344.033 & 111.077 & 112.376 & 5.709 & 424.622 \\
\hline Tide & -0.094 & 2.329 & -3.270 & 2.990 & -0.002 & 2.258 & -3.420 & 3.210 \\
\hline
\end{tabular}

